\title{
Common Points in the Policy of Italy and Central Europe
}

\author{
PETRA HAMERLI
}

\section{$\$$ sciendo}

Politics in Central Europe (ISSN: 1801-3422)

Vol. 16, No. 1S

DOI: $10.2478 /$ pce-2020-0003

\begin{abstract}
Recent news often compares current Italian policy to that of Central Europe especially Hungary. The latest elections brought victory to right-wing populism in Italy and the Visegrad countries - especially in Hungary and Poland - with the key points of their discourse concentrated on similar topics such as Euroscepticism, migration and security, which are tightly connected to the refugee question. Right-wing theories have historical traditions both in Italy (Fascism) and Central Europe (rightist and extreme rightist parties) that I think important to summarise, as some of their elements can also be found in the political thinking of nowadays. The paper presents the main parties of Italy and those of the Visegrad countries and compares their common elements to see whether Italy can politically belong to Central Europe.
\end{abstract}

Keywords: Populism, Italy and the Visegrad Group, Euroscepticism, Migration.

\section{Introduction}

In the spring of 2018, the Italian political situation changed a lot as, instead of the previous leftist government, the populist parties gained victory in the elections. The majority of the votes were given to Movimento 5 Stelle, a "third way party" whose programme is full of ambivalences - e.g. regarding the migration question, as the welcoming of migrants is, in principle, refuted by the party but at the same time, it agrees with the quota system. The key figure of Italian political life is Matteo Salvini, the leader of Lega, which is characterised by Euroscepticism and anti-migration. Similar goals have been declared by the majority of the Central European parties and recently, Italy has begun to approach one of the Visegrad 
Countries, Hungary. This raises the question of whether Italy is politically part of Central Europe. Geographically, the country belongs to Southern Europe, while Italians sometimes prefer to define themselves as Western Europeans. Nevertheless, the Northern regions of Italy are often considered parts of Central Europe because of the similarities in historical-political development. In my paper, I make an attempt to summarise the similarities and differences of Italian and Central European political thinking through presenting the most significant parties' goals. First, I introduce the historical roots, followed by presenting the key points of the ideas of these parties of Italy and Central Europe, and, as a conclusion, I summarise the common features of Italy's and the Visegrad Group's programmes.

\section{Historical Roots}

Italy was unified in 1861 under the Kingdom of Victor Emmanuel II (Savoia Dinasty), King of Piedmont-Sardinia, who is still nowadays respected as the father of the Italian state. The unification was realised due to the Risorgimento ${ }^{1}$ movement that aimed for the formation of the politically and culturally quite different Italian city states into one nation-state, and its leader was Giuseppe Mazzini, whose name became the symbol of the national unity in Italy ${ }^{2}$ (Biagini 2016). Even so, diversity among the regions of the country still exists and the common conflicts between the southern and northern part of Italy are well known, as well as the fact that Rome is often considered a separated entity within the country. These three parts of Italy - Southern Italy, Northern Italy and Rome - quite significantly differ from each other regarding the customs and traditions of the inhabitants and the 'southern question' is one of the most significant problems that the political parties still have to deal with.

It is my persuasion that a country's political system cannot be understood without knowing the historical roots that influenced the policy-making of the examined state, so I think it necessary to make an outline on those stages of Italy's history - comparing them to Central European characteristics - that can be considered historical roots of the political culture of nowadays. In my opinion, in both cases, it originates from the Interwar Period.

Italy's political system was formed after the unification of the country and is often called the 'Liberal Era', when social reforms were made by the Governments which frequently rotated around each other. As a result of earlier disintegrity, the country was characterised by linguistic, cultural, political and economical diversification. This caused general dissatisfaction within society

1 This research project was supported by the European Union. EFOP-3.6.3-VEKOP-16-2017-00007 - Young researchers from talented students - Fostering scientific careers in higher education. The word Risorgimento literally means rebirth.

2 In the unification Camillo Benso, Count of Cavour - the Premier of Piedmont-Sardinia - and General Giuseppe Garibaldi, played an important role as well and they are also respected as national heroes of Italy. 
which resulted in demonstrations and strikes. The Governments followed the policy of transformism, which resulted in an adaptation to existing circumstances (Tanács-Mandák - Nuber 2017: 16-20.). The social, political and economic crisis deepened after the Great War (1914-1918), which ended with a delusion of the Italians as, at the Paris Peace Conference in 1919, Italy did not gain all the territories promised to it in return for joining the Entente Powers. ${ }^{3}$

These factors combined resulted in the strengthening of the rightist movements and a group of returning ex-soldiers, together with the followers of Futurism ${ }^{4}$ and young nationalists, founded the Fascio di Combattimento, a movement that propagated the importance of Italy's interests and social reforms. The Fasci were organised regionally - this regional organisation of political groups having traditions even today in Italy - and they fused into the National Fascist Party in 1921 under the leadership of Benito Mussolini, who became Prime Minister of Italy in 1922 and established the one party system in the country (De Felice 1966).

Fascism (1922-1943) was a determining period in the history of Italy. ${ }^{5}$ Before summarising very briefly its most significant elements, I think it is important to note that the expressions 'Fascism' and 'neofascism' are - as a heritage of Communist historical-political thinking - often used in terms of all the extreme rigth-wing parties, which is incorrect: historically, only one type of Fascism existed, which is the Italian one; the regime of Mussolini. This is why the expression should be used just in the case of Italy. Now back to Mussolini's theories, which dominated Italian politics for over two decades, and fascism aimed at totalitarianism. In order to stay in power, Mussolini had to accept that the governing form would remain a monarchy - the King was Victor Emmanuel III (1900-1946) - and, as the the majority of Italian society insisted on Catholicism, the Duke had to make a compromise with the Catholic Church (Lateran Pacts 1929). These decades were characterised by - at least apparently - a certain stability in the inner affairs and an expansionist foreign policy which aimed to make Italy one of the Great Powers of Europe (Ormos 2019).

In my point of view, Fascism is a typical example of early populism. To verify this, it is necessary to define briefly what populism is. The Italian politologist, Ilvo Diamanti, and his French colleague, Marc Lazar, say that it is a complex and hardly definable concept which is present in the ideologies of all the mass

3 At the breakout of the Great War, Italy remained neutral but there was a group of interventionists - with Benito Mussolini among them - who voted to enter into the war for territorial gain. The nationalist interventionists claimed South-Tyrol, the Istria and the Dalmatian Coast and the Entente Powers promised them to Italy with the secret Treaty of London (1915). After the birth of the Kingdom of Serbs, Croats and Slovenes, these promises could not be fulfilled, which led to a general delusion of Italian society.

4 Futurism is an artistic movement born in Italy in the early 1900s, which emphasised the importance of technology modernisation, violence, war and youth.

5 As we will see, Fascist elements are still present in certain Italian political circles. 
parties and which has roots going back to the $19^{\text {th }}$ century, when 'the people' became an important actor in policy-making. Populism usually appears after some political, social or economic crisis and its modern form has been becoming a significant element of policy from the 1980s (Diamanti-Lazar 2018: 16-31). Roberto Biorcio, another Italian scientist, explains that it cannot be described as an organic ideology, however, there are some typical features that are present in all the populist parties' programmes. At the center of all of them, there is the 'folk', the people, and the goals conceived by the party leaders serve to 'defend people's interests', where 'people' refers to a homogeneous social unit. Every populist party and movement has a leader who is 'working for the people' and who is often charismatic. Besides the 'people' and the 'leader', a third common element of all the forms of populism is that the 'people' always have an 'enemy'. (Biorcio 2012: 2.). The Hungarian politologist, József Bayer, completes these points of view with the statement that populism refers to the way of policy-making and the discourse and not on the manner of political programmes. This means that the discourse - how content is expressed in the programme - is much more important than the content itself (Bayer 2002).

How do all of these elements appear in Fascism? It can be pointed out that Fascism did not mean an organic ideology as it had always been adapting to momentary circumstances. The best example of this is the case of the racial acts: originally, Mussolini did not make a difference among the people based on ethnicity but at the end of the 1930s, as Adolf Hitler's Nazi Germany became a more and more dominant factor in the international relations of Europe, Mussolini introduced measures against Jewish people (Ormos 2019). Mussolini can be considered a charismatic leader, as he embodied the iron-handed 'father' of the Italian nation who took care of all the Italians. This myth was not only diffused among Fascists but the majority of society accepted it (Andreides 2014). Mussolini wanted to 'reform' the Italian people - il popolo, as he called it - into a society full of agile and strong young people and he was able to influence them through his well-structured speeches. He made the Italians believe that he could transform - according to the interests of the popolo - Italy to be a significant Great Power of Europe. Besides the leader and the popolo in the center, in Fascism, 'enemies' can be found as well; the main ones being the Freemasons and the Communists (Ormos 2019. and De Felice 1974).

Mussolini lost his popularity and authority because of the alliance with Hitler made in 1936, which led to the participation of Italy in the Second World War (1939-1945, Italy joined in 1940). The resistance - which had been existing during the whole Fascist period - strengthened, and, as a consequence of the defeats in the war, Mussolini was failed by his own party comrades (25 July, 1943). This resulted in King Victor Emmanuel III being imprisoned by Mussolini who nominated Prime Minister Pietro Badoglio who later liquidated the Fascist Party and the Southern Kingdom capitulated in September, 1943. In the mean- 
time, Mussolini - who was liberated from prison by Nazi soldiers - became the Head of the Republic of Salò (Italian Social Republic), which was a puppet state created in the northern part of Italy, a territory invaded by the Germans. After the Second World War, German occupation ended in the region and Mussolini was executed by the Italians on 28 April, 1945 (Candeloro 2014).

In the meantime, in Central Europe, a dual state, the Austro-Hungarian Monarchy, was formed in 1867. Under the reign of Franz Joseph I (in the Monarchy: 1867-1916, in Austria: 1848-1916), the state enjoyed relative stability and modernisation. Just like Italy, Austria-Hungary was also characterised by diversity but there was a huge difference between them: while in Italy, regional differences could be found within one nation, the Monarchy was a multi-ethnic state with approximately a dozen different ethnic groups. As the $19^{\text {th }}$ century can be considered the century of nation state building, the minorities of the Monarchy also targeted independence which, in the long-term, led to the collapse of Austria-Hungary.

During the Interwar Period, nationalism also appeared in the Central European countries. Successor states formed, instead of Monarchies, aimed at national homogeneity. As the different ethnic groups of the former Hapsburg Empire mingled during the centuries, homogeneity was impossible to gain and the new countries were, in reality, "multi-ethnic nation states", as the Historian László Szarka calls them (Szarka 2016). The governments of these countries introduced different measures - agrarian reforms or limitations of minorities' laws - to assimilate the minorities which sometimes - like the Iron Guard in Romania - led to chauvinism.

As all of these countries gained huge territories from Hungary, here, nationalism appeared mainly through revisionism and rightist parties and movements started to form under the slogan of "protecting the Hungarian nation". The most extremist one was the Arrow Cross Party which, after a series of inner transformations, took on its final form in 1944 and, with the help of the Nazis, it managed to gain the power until the end of the Second World War. Just like the northern part of Italy, Hungary also suffered a German invasion during these years. The ideology of the Arrow Cross Party is called Hungarism and also included some elements of early populism. It had a charismatic leader, Ferenc Szálasi, the Nemzetvezetó (Head of the Nation), who considered himself the unifier of "Hungarian people within and outside the frontiers". Within the Hungarian nation, the most significant element of society was the peasantry, as Szálasi thought that agricultural work - which produced the meals - meant a basic necessity for people to survive. As with populist movements in general, Hungarism also found its enemies in Jewish people who were considered the evocators of "Hungarian Tragedy"6 (Paksa 2012).

6 In the Interwar Period "Hungarian Tragedy" meant the situation created by the Treaty of Trianon (1920), which led to the loss of two thirds of historical Hungary's territories. 
Regarding the other Visegrad Group countries - Czech Republic, Poland and Slovakia - rightist movements were present there as well. The Czech Republic and Slovakia formed a common state under the name Czechoslovakia, where populism appeared in Hlinkova Slovenská l'Udová Strana (Hlinka's Slovakian People's Party), led by the charismatic Andrej Hlinka, who targeted the autonomy of Slovakia. Besides the leader, the 'enemies' appeared in the party's ideology among its populist features. Hlinka considered the Hungarian minority, the Communists, the Jewish people and all the leftist theories as enemies (Waczławczyk-Laros 2017: 49). In Poland, Marshall Józef Piłsudski, the first President of the Second Polish Republic (1918-1922), a member of the Parti Polska Socjalistyczna (Polish Socialist Party), established an authoritarian regime (1926-1935) which can be considered populist in terms of the role of its leader, as Piłsudski was respected as the "father" of the country (Kochanowski 2002).

This summary shows that, during the Interwar Period, an early form of populism was present both in Italy and Central Europe. After the Second World War, both territories' situations were quite different. Regarding Italy, Diamanti and Lazar, in their common book, say that populism was present in the leftist programmes, as the Partito Communista Italiano (Italian Communist Party, PCI) used its elements during the Resistenza (Resistence). It means a political activity of the antifascist groups - Communists, Monarchists, Christian Democrats, Socialists, Liberalists and Republicians - in majority united in Comitato di Liberazione Nazionale (Comittee of National Liberty). The Antifascist Resistence was led by the head of the PCI, Palmiro Togliatti, who targeted the unification of the Italian people for the civic-democratic transformation of the country (Diamanti-Lazar 2018: 77). This activity ended with the proclamation of the First Italian Republic on 2 June, 1946, which was a result of a referendum that can be considered a common method of populism to demonstrate to the people that they can actively participate in policy-making. After that, populism appears again in the 1980s in Forza Italia (FI), led by Silvio Berlusconi, and in Lega Nord, founded by Umberto Bossi (Diamanti-Lazar 2018: 111 - 112.), which will be presented later in more detail as part of the present study.

Regarding Central Europe, the region belonged to the sovietised regimes, so between 1945 and 1990, the main ideology in these countries was Communism or maybe it is better to say 'Communisms', as the regimes were built upon in different ways in each countries. The present study does not aim to analyse this question, rather, it focuses on populism which, of course, is itself represented in the Communist parties' ideologies as well. Each of these parties had a leader who used propaganda to demonstrate that they were able to change the life circumstances of society and to make all members of 'the people' equal - the usual governing form of Communist regimes in 'People's Republics', with the aim of showing that the people can take part in policy making. The birth of the Hungarian Constitution on 20 August 1949 can be mentioned as a good example 
of the measures taken by these parties to make people believe this, as this constitution was the first written one in the history of Hungary (Vörös 2016: 26).

After the collapse of the Soviet Union, the Communist regimes failed in Central Europe as well and, from the 1990s, such as in Italy and also in this region, right-wing populism began to diffuse. Henceforward, after presenting the roots of populism, I shall refer to its current situation in the two territories.

\section{The Current Situation in Italy}

The latest elections held on 4 March, 2018, brought victory to populism in Italy: the Movimento 5 Stelle (5 Stars' Movement), which defines itself as a 'third way party', got the majority of the votes $(32.7 \%){ }^{7}$ It means that Movimento 5 Stelle does not belong to either of the two traditional coalitions; to Centrodestra (centre-right) or Centrosinistra (centre-left). Although one of the parties of Centrosinistra, the Partito Democratico (PD), came in second place with $18.7 \%$, the Centrodestra won the right to participate in a government reshuffle as its two strongest parties, Lega (the former Lega Nord, Northern League) and Forza Italia (Force Italy) altogether got $31.4 \%$ of the votes ( $17.4 \%$ by Lega, and $14 \%$ by FI) ${ }^{8}$ These three parties (Forza Italia, Lega and Movimento 5 Stelle) are all populists.

Among the modern Italian parties, the first populist one was that of Silvio Berlusconi, a typical charismatic leader who, as a media-man (the founder of Fininvest), used mass-media to influence the people. Berlusconi founded his party in 1994 with the concrete aim of changing the Italian political structure, characterised earlier by the Christian Democratic-Communist bipolarity. His slogan was "In the name of the people", which helped him gain sympathy from the masses. In the beginning, he propagated that Forza Italia was not a party but a movement which was able to change the future of Italy (Tanács-MandákNuber 2017: 161-163). He gained success in the elections of the same year due to his promises which offered economic freedom, meritocracy and a possibility for 'the people' to dismiss the "corrupt political elites" that had governed Italy from 1946 (Ruzza-Balbo 2013: 167). Later, in terms of personalisation of the policy, he made 'the people' believe that he could guarantee a positive development of the country and that he was always acting according to the interests of the Italians. He presented his media career to the public as an example of how every Italian could benefit from a good-working political system. Although it was revealed soon after that he was motivated mainly by his own ambitions to gain power (Tanács-Mandák-Nuber 2017: 161-163), the FI remained one of the strongest parties of Centrodestra.

7 See the results of the elections on the site of La Repubblica. Available at: https://elezioni.repubblica. it/2018/cameradeideputati (19 January 2019).

8 Available at: https://elezioni.repubblica.it/2018/cameradeideputati (19 January 2019). 
Another populist party in Italy is Lega Nord, founded in 1991 with a fusion of six regional groups under the leadership of Umberto Bossi (Molnár 2002: 74), who, like Berlusconi, was a charismatic leader as well but there was a huge difference between the two politicians: while Berlusconi - as we could see embodied the successful businessman, Bossi came from a small village, from a modest family and represented traditional values like being proud of ones origin and the importance of family. This background helped Bossi become the head of a traditional community which contributed to the success of an ethno-national ideology that Lega Nord represented (Ruzza-Balbo 2013: 168-169). The followers of the party often expressed that they felt during the speeches of Bossi that he was giving shape to their own thoughts. Thanks to this, the party was attractive to the - especially Northern Italian - voters (Passarelli-Tourto 2012: 129). He used a language in his remarks which was closer to the common way of expression than the traditional political language in order to emphasise his difference from the politicians of Rome. Bossi's slogan was "Against Rome", which meant that he was opposed to the traditional Italian party system and the previous Governments (Molnár 2002: 77).

In the original programme of Lega Nord, hate towards Southern Italy and Rome, a willingness for separatism or, at the very least, a federal transformation of Italy, along with xenophobia, were present. In the 1990s, criticism of state bureaucracy and traditional parties were then added. With these new aspects, it later gained more support from the moderated part of society of Northern Italy as well (Molnár 2002: 74-75). Hate towards Southern Italy turned to anti-migration which was explained with the necessity of defending territorial identity and security. The latter one was - and still is - a key point in the discourse of Lega Nord, as Bossi and his followers explained that security is endangered by the "aliens" coming into the country. After the terrorist attacks in New York on 11 September, 2001, an anti-Islamic statement was added to the previous aspects and Lega Nord began to emphasise in its discourse that the party could be a defender of Christian values from the Islamic culture's diffusion through migration. Connected to this, Lega Nord supports every foreign policy step which is explainable as a measure to defend European values from the diffusion of Islamic culture (Passarelli-Tourto 2012: 117-126). Regarding Lega Nord's statement on the European Union, its Euroscepticism is strong, which can be said to have originated from the fact that, after Italy joined the European Monetary Union, the majority of Northern Italians were not interested in separatism anymore, which led to a weakening in support of the party by the electorate (Molnár 2002: 158).

Since 2013, the new president of Lega Nord has been Matteo Salvini, the actual Home Secretary. He, like Bossi, is a charismatic leader as well, who pays special attention to the way of political communication. In order to modernise Lega Nord's way of connecting with the people, he prefers the use of social 
networks, posting comments to his personal sites. This technique seems to work well as Salvini managed to gain popularity not just in the Northern regions of Italy but also in other territories of the country. (Passarelli-Tourto 2018.) Salvini managed to transform Lega Nord from a regional party to a national one - the change of the name into Lega expresses this - with a programme whose key point is Euroscepticism (Diamanti-Lazar 2018: 116): while Lega Nord of Bossi propagated that the local identity of Northern Italians should be preserved by the federal transformation of Italy, Lega of Salvini says that the Italians' national identity should be defended from the European Union and from migration (Passarelli-Tourto 2018).

In 2018, Lega and Forza Italia participated as part of Centrodestra in the elections, which was by no means not the first occasion. I do not wish to enter into the details of the forming of the relations of the two parties but, in brief, they were in multiple coalitions and at the beginning of the 1990s, Alleanza Nazionale ${ }^{9}$ (National Alliance) of Gianfranco Fini joined them as well (Ruzza-Balbo 2013: 170). Originally, Alleanza Nazionale had a programme with neofascist elements, among which the asseveration of the importance of national unity caused a debate in 1995 between Bossi and Fini, as the latter targeted the separation of the Northern region of the country from Rome and Southern Italy (Ruzza-Balbo 2013: 170). In the same year, Bossi secluded his party from an alliance with Berlusconi and Fini. It was revealed soon after that Lega Nord was not able to gain enough support to become a determining factor in Italian politics so Bossi decided to renew the alliance with Forza Italia in 1999 (Molnár 2002: 85-95).

Despite the disagreements between Bossi and Fini, in 2002, they together drew up a draft in order to limit illegal migration towards Italy - the Bossi-Fini Law - which regulated settlement criteria in Italy and introduced a punishment for those persons and civil organisations caught helping illegal migration (Innocenzi 2016: 29). The law ordered that job-seeking individuals in Italy had to have a valid employment contract. In the event of losing their job, the individual could only remain in Italy if they found another job within six months. Besides this, the law increased the role of regional authorities in dealing with migration (Glied-Keserú 2016: 280). The Bossi-Fini law cannot be considered successful, as tar-spinkler has deep traditions in the country, so persons living illegally in Italy cannot always be discovered (Innocenzi 2016: 30).

9 The party's predecessor was Movimento Sociale Italiano (Italian Social Movement), founded in 1946, which grew out of the traditions of the Republic of Salò. In 1972, the party fused with the monarchists and changed its name to Movimento Sociale Italiano - Destra Nazionale (National Right-Wing). In 1995, the party was merged into Alleanza Nazionale, led by Gianfranco Fini, which merged with Forza Italia under the common name Popolo della Libertà, which broke up in 2011. Nowadays, Alleanza Nazionale is united with Fratelli d'Italia (Italy's Brothers) and led by Giorgia Meloni in 2014. (Ruzza-Balbo 2013.) 
On the latest elections, Forza Italia and Lega Nord - together with the other parties, Fratelli d'Italia and Noi con l'Italia - Unione di Centro ${ }^{10}$ of Centrodestra participated with a common programme made with compromises. It summarises the four parties' principles across 10 points, with the slogan "For increase, families, security and full employment", reflecting on the main problems of Italian society - main problems for the 'people'. The programme - as is usual with populist programmes - is built upon promises that offer solutions for those circumstances that make the majority of Italians unsatisfied. Regarding "increase", it promises a reduction in taxes, support of Italian small businesses, a development programme for the industrialisation of the Southern regions and protecting "Made in Italy" products. The programme declares that the nucleus of society should be family and proposes to increase birth rates in the country while also promising special attention to young mothers' possibilities of employment. Other social measures are included as well, such as supporting Italians living in poverty, increasing pensions, ameliorating the sanitary system and approving meritocracy in schools and universities. The promise of full employment for Italians - with special attention given to younger generations - also belongs to social measures. For Centrodestra, resolving the problem of the refugees and providing security is a question of high priority. Regarding this, the programme includes the necessity of repatriation for all refugees ("clandestini") and resolving their problem with a 'Marshall Plan to Africa'. The reintroduction of border control and the blocking of debarkation of refugee-ships are also considered to be necessary. Of course, Euroscepticism also appears in the programme of Centrodestra as a common idea of the four parties and it has been declared that the EU should intervene less with Italian inner affairs and that sovereignity should be returned. ${ }^{11}$

The third populist party, Movimento 5 Stelle, which won a majority in the latest elections, is a relatively new party in Italy. The party was founded in 2009 by Beppe Grillo, who was originally a comedian from Genova. Before founding his movement (party), he often criticised the actual politics of Italy through the television programmes that hosted him. He used - both as a comic and, later, as a politician - an anti-politics and anti-elite rhetoric, and - like Berlusconi and Bossi - was opposed to the traditional way of policy-making and targeted a personalisation of politics. Like Salvini, he also used the Internet for communication with the electorate which contributed to the party's success. (Chiapponi 2012.)

In 2005, Grillo started a blog which offered a wide range of topics that criticised Italian politics. The blog soon had numerous followers, especially from

10 Noi con l'Italia - Unione di Centro (UDC) is a Christian Democratic coalition formed in January, 2018.

11 Available at: http://www.forza-italia.it/speciali/Programma_centrodestra_condiviso_10_PUNTI.pdf (19 January 2019). 
the younger generation, who began to see in Grillo their voice to express their generation's problems. Besides this, ecological questions and, through Italian intervention in the Iraq conflict (2003-2011), pacifism were at the center of the blog's tags. As Grillo saw the attendance to his blog, he began - in 2005 - to organise occasions - called Meetup - where the problems brought up on the blog could be negotiated. As these occasions seemed to be successful, in 2007, Grillo suggested to create liste civiche (Civic Lists) ${ }^{12}$ that express the agreement of the signers with "five stars" ( 5 stelle), which symbolise the central elements of the programme: water, energy, connectivity, rubbish collection and social services. In 2009 , Grillo - using a formula adapted frequently by populist politicians - communicated that he did not want to found a party but a movement with a programme. (Bertocchini 2016: 49-52.)

This movement was born to protest against the current situation of Italy, current government, the traditional parties, etc., and offers an alternative way of policy making, claiming a radical change in Italian politics (Passarelli-Tourto, 2018). The programme made for the elections of 2018 was entitled "A programme written by the Italians", with the subtitle "The first program in the world voted online by the citizens", ${ }^{13}$ as the topics included were negotiated. The long phrases of the programme attempted to refer to all the current problems of Italy, such as ecological, social and economic problems, which could be analysed over several pages. Here, I extract only those points that are present in Centrodestra's programmes as well: Euroscepticism, migration and security. The Euroscepticism of Movimento 5 Stelle emphasises in particular the importance of supporting the Made in Italy products which, according to the party, can be damaged by EU commercial policy. Regarding EU bureaucracy, Movimento 5 Stelle requests a transparency in financial matters and the publicity of negotiations. ${ }^{14}$ About the EU's migration policy, it says that Italy cannot be a refugee camp so a collaboration among EU members is necessary in dealing with the question, and that illegal migrants should be repatriated..$^{15}$ Likewise, the party emphasises the importance of security for Italian citizens, including personal rights and liberty as well. ${ }^{16}$

To sum up the Italian governing parties' programmes, it can be seen that Euroscepticism, the migration question and security are key points for all of

12 Lista civica (plural: liste civiche) in Italy means a party list presented on a local election which is not connected officially to national political parties.

13 Available at: https://www.movimento5stelle.it/programma/index.html (19 January 2019).

14 Available at: https://www.movimento5stelle.it/programma/wp-content/uploads/2018/02/Unione-Europea.pdf (19 January 2019).

15 Available at: https://www.movimento5stelle.it/programma/wp-content/uploads/2018/02/Immigrazione. pdf (19 January 2019).

16 Available at: https://www.movimento5stelle.it/programma/wp-content/uploads/2018/02/Sicurezza.pdf (19 January 2019). 
them. Both in the common programme of Centrodestra and in that of Movimento 5 Stelle, it appears that instead of EU imports, Made in Italy products should be given priority, which promotes the protection of the national economy. Regarding the migration question, Lega represents an anti-migration and anti-Islam position the most within Centrodestra. The security question is tightly connected to immigration, as all three populist parties agree that the increasing number of illegal migrants in Italy causes a decrease in the sense of security by the Italian citizens.

\section{The Central European Situation Compared with Italian Trends}

Reading the key points of the Italian parties' programmes, Central Europeans certainly find them familiar, as similar problems are in the limelight of the policies of the Visegrad Group as well. Many online posts and articles draw a parallel among Italy and the Visegrad Group because populist parties govern in both territories and Euroscepticism and anti-migration is a common feature of their programmes.

As I already mentioned, in Central Europe, populism diffused after the failure of Communism. The change of the regime did not bring the expected results which caused a political crisis that led to the diffusion of right-wing populism as it refuses the existing political and social system and usually rejects individualism and the market economy. These movements aim to establish a strong, centralised state but, at least in principle, they are not opposed to democracy (Bayer 2002). Still, according to Bayer, in Central Europe, early agrarian populism has traditions which, in the Interwar Period, refused industrial capitalism maintained by 'aliens'. This tradition is connected to economic populism which targets an enclosed national economy controlled by the state and tries to seclude itself from the effects of the world economy. A third form of populism is present as well in the Visegrad Group - and this is currently the most diffused one - which is political populism, characterised by nationalism, xenophobia and anti-globalism. (Bayer 2002.)

According to a study by Tamás Boros and Tibor Kadlót, in the Czech Republic, around $50 \%$ of the electorate voted for some of the populist parties. Here, both right-wing and left-wing populism can be found, such as the eurosceptic Svobodni (Party of Free Citizens) and the anti-migration Úsvit (Dawn - National Coalition) - which wants the Czech Republic to leave the EU - as right-wing nationalists, and KSČM (Communist Party of Chech Republic), whose support is around $11 \%$ of the electorate, as left-wing. The biggest party of the governing coalition, ANO 2011, is a centrist-populist political group that was founded to express the general dissatisfaction of the Czech people. The support of populism in Hungary is extremely high, as almost two thirds of voters prefer right-wing populists such as FIDESZ and Jobbik, both of them eurosceptic and anti-migrant 
parties. In Poland, the right-wing populist parties are supported by around half of the electorate. The most significant among them is the actual governing party, Prawo i Sprawiedliwość (Law and Justice), which was founded by Lech and Jarosław Kaczyński in 2001. Last but not least, in Slovakia, the extreme right parties' support has been growing recently. The most significant ones are Slovenská Národná Strana (Slovakian National Party) and L’Udová Strana Maše Slovensko (People's Party Our Slovakia), both of them nationalists and eurosceptics, and L'Udová Strana Maše Slovensko's programme includes anti-globalisation, anti-migration, anti-Ziganism and antisemitism as well (Boros-Kadlót 2016).

In her study, Věra Stojarová summarises the common elements of the programmes of Visegrad countries' populist parties. As she points out, nationalism, Euroscepticism and anti-migration are present in each of them and in some cases - such as the programme of Jobbik and L'Udová Strana Maše Slovensko the anti-Roma and the anti-Jewish statement is also added to these. That said, Jobbik has recently started changing its image. As the former President, Gábor Vona, explained in 2015, he wanted to transform his party from an extremist to mainstream one and decided to moderate his rhetoric. Still, despite radical elements such as racism, hints of the revision of Trianon are eliminated from the discourse of Jobbik (Stojarová 2018).

Now, the key points of these parties are Euroscepticism and anti-migration, with the security question (or put another way: the danger of terrorism) tightly connected to them. As we can see, the situation is the same in the Italian parties' case, so Italy and Central Europe can be connected to each other at this point. According to an analysis by Anna Molnár, in the early 2000's, Italian public opinion was in favour of EU integration but in the center-right parties' programmes, Euroscepticism was already present as their leaders, Berlusconi and Bossi, felt that it could limit the sovereignity of Italy. Later, Euroscepticism began to diffuse, mainly because of the increasing economic crisis that followed the introduction of the Euro to the country (Molnár 2016). As we can see from the above, Euroscepticism appears in the programmes of all the three mentioned parties, as their politicians think that EU integration results in an EU that is too involved in its members' internal affairs (Passarelli-Tourto 2018).

The aforementioned Central European populist parties are share the same statement, especially because of the EU's plan to deal with the refugee problem with the introduction of a quota system that obligates all EU member states to accept a certain number of migrants/ refugees. In 2015, migration became multitudinous and as a consequence, the Hungarian Prime Minister, Viktor Orbán, argued for the protection of national interests and closed up the borders to migration; the other three Visegrad countries also took up this statement (Schmidt, 2016). As Visegrad Group leaders agree that migration increases the danger of terrorism, they decided not to accept any of the refugees. In their discourse, they argue with an importance on the defense of European 
civilisation which can be damaged by the spread of Islamic culture (Stojarová 2018). As I have already mentioned, Lega is anti-Islam as well, so this can be considered another common feature. Both in Italy and in Central Europe, the populist parties propagate that security can be guaranteed only by refusing to accept migrants. At this point, Italian and Central European interests seem to be in harmony but it should not be forgotten that Italy - as a huge number of migrants try to enter Europe via Mediterranean coastlines and land on Italian soil first - is logically interested in the introduction of a quota system which, for the Italians, would mean a decrease in the number of migrants living in the country. This statement is expressed in the programme of Movimento 5 Stelle, ${ }^{17}$ as Forza Italia and Lega Nord are for the repatriation of all refugees. ${ }^{18}$

Current daily news often brings up the possibility of an anti-migration alliance between Italy and the Visegrad Group, as their political discourses are in harmony. Most of this news speaks about a possible agreement between Salvini and Orbán - who recently, on May 2, 2019, had a meeting to negotiate the matter - as both of them follow an anti-migration policy "in defense of Christian-European values", as they explain. An ideological agreement is undoubtedly possible as both of the politicians share the statement that refugees and migrants should be sent back to their homeland and helped by the EU there but the Italian public opinion's point of view is that it would not resolve the migration problem. Geo-politically, the Visegrad countries are not an the center of migration so for them, the protection of European culture is rather an ideological question, while for Italy, it is a real problem for two reasons: On one hand, Italy feels responsible for saving the lives of migrants arriving across the Mediterranean Sea but on the other hand, both Italian public opinion and the actual governing parties are of the statement that migration endangers security in the Mediterranean and that this security should be defended by the Italian Government. ${ }^{19}$ Some Italians criticise the Visegrad Group for not accepting refugees and they judge Salvini because of the approach of these countries. These critiques affirm that, despite the similarities of the populist parties' rhetoric in Italy and in the Visegrad countries, the two territories' long-term interests can be different, so Italy probably won't become part of Central Europe. ${ }^{20}$ This goes without saying that it is just a guess - the future will come to a decision on this

17 Available at: https://www.movimento5stelle.it/programma/wp-content/uploads/2018/02/Immigrazione. pdf (19 January 2019).

18 Available at: http://www.forza-italia.it/speciali/Programma_centrodestra_condiviso_10_PUNTI.pdf (19 January 2019).

19 Available at: http://www.occhidellaguerra.it/migranti-rifugiati-accoglienza-le-differenze-italia-visegrad/ (19 January 2019).

20 Available at: https://www.nextquotidiano.it/visegrad-salvini-conte/ and https://www.avvenire.it/attualita/pagine/orban-salvini (19 January 2019). 
question - an answer whose construction mainly depends on whether Salvini would be able to maintain his influence over Italian policy-making.

To sum up, populism has historical roots and it is becoming a significant factor in policy-making both in Italy and Central Europe since it offers solutions to those problems which make the majority of society unsatisfied. These problems are similar in both regions - Euroscepticism, migration and security - and the aforementioned parties use more or less the same rhetoric as they argue with the importance of defending national identity, European and Christian values, sovereignity and security. Because of these similarities, it seems that a possible alliance is currently forming between Italy and the Visegrad Group but, in the meantime, it is becoming more and more evident that there is a huge difference between some basic interests which could result Italy's drawing-away from Central Europe.

\section{References}

\section{Daily News}

Drogo, G. (2018): „Come gli amici di Visegrad di Salvini hanno fregato Conte sui migranti." Next available at https://www.nextquotidiano.it/visegrad-salvini-conte/ (19 January 2019)

"Migranti. Orban incontra Salvini: nessun aiuto per i ricollocamenti." Avvenire available at https:// www.avvenire.it/attualita/pagine/orban-salvini (19 January 2019)

Muratore, A. (2018): „Migranti, rifugiati e accoglienza: le differenze tra l'Italia e Visegrad”. Gli Occhi della Guerra (7 June) available at http://www.occhidellaguerra.it/migranti-rifugiati-accoglienza-le-differenze-italia-visegrad/ (19 January 2019)

\section{Party Programmes}

Il programma del Centrodestra available at http://www.forza-italia.it/speciali/Programma_centrodestra_condiviso_10_PUNTI.pdf (19 January 2019)

Il programma del Movimento delle 5 Stelle available at https://www.movimento5stelle.it/ programma/index.html (19 January 2019)

\section{Papers and Books}

Andreides, G. (2014): A változó Mussolini-kép és a mussolinizmus. Múltunk 2014 (2): 124-147.

Bayer, J. (2002): Jobboldali populizmus és a szélsőjobboldal Kelet-Közép-Európában, Eszmélet available at http://www.eszmelet.hu/bayer_jozsef-jobboldali-populizmus-es-aszelsojobboldal-kele/ (19 January 2019)

Bertoccini, I. (2016): Il populismo in Italia. Il caso di Lega Nord e M5S. Thesis. Libera Università degli Studi Sociali, Dipartimento di Scienze Politiche. 
Biagini, A. F. (2016): Per un'introduzione al Risorgimento in Italia, in Carteny, A. - Pelaggi, S. eds., Stato, Chiesa e Nazione in Italia. Contributi sul Risorgimento italiano, 13-20, Edizioni Nuova Cultura.

Biorcio, R. (2012): I populismi in Italia. Rivista delle Politiche Sociali available at http://www. scuoladiculturapolitica.it/sitoSCP2012/bibliografia/Modulo4-Roberto_Biorcio-doc1.pdf (19 January 2019)

Boros T. - Kadlót T. (2016): A populizmus helyzete az Európai Unióban. Populista trendek és témák 2016-ban. Policy Solutions - Friedrich-Ebert-Stiftung available at https://library.fes.de/ pdf-files/bueros/budapest/12992.pdf (19 January 2019)

Candeloro, G. (2014): Storia dell'Italia moderna. Vol. 10. La seconda guerra mondiale. Il crollo del fascismo. La resistenza. 1939-1945. Feltrinelli Editore.

Chiapponi, F. (2012): Il populismo 2.0. Note preliminari sulla leadership e sul modello organizzativo del Movimento 5 Stelle. Studi Piacentini, 2012: 302-316.

De Felice, R. (1966): Mussolini il fascista. Vol. 1. La conquista del potere, 1921-1925. Collana Biblioteca di Cultura Storica. Einaudi Editore.

Diamanti, I. - Lazar, M. (2018): Popolocrazia. La metamorfosi delle nostre democrazie. Editore Laterza.

Glied, V.-Keserű, D. (2016): Migrációs kihívások az Európai Unióban. In: Tarrósy, I.-Glied, V.-Vörös, Z. (2016): Migráció a 21. században. Publikon Kiadó. 259-293.

Innocenzi, N. (2016): L'operazione Mare Nostrum. La politica migratoria italiana tra assistenza umana e politiche di sicurezza. Aguaplano Editore.

Jaromin, K. (2016): Euroscepticism Taking Over Europe. Will Poland Spearhead It? European Student Think Tank available at https://web.archive.org/web/20161231170127/https://europeanstudentthinktank.com/2016/01/21/euroscepticism-taking-over-europe-will-poland-spearhead-it/\# (19 January 2019)

Kochanowski, J. (2002): Szempontok a Horthy- és a Piłsudski-rendszer összehasonlításához. Világtörténet, 2002 (2): 3-19.

Molnár, A. (2002): Az Északi Liga szerepe Olaszország tartományi rendszerének átalakulásában. Doktori értekezés. Budapesti Közigazgatási és Államtudományi Egyetem, Nemzetközi Kapcsolatok Tanszék.

Molnár, A. (2016): Economic Crisis and Euroscepticism: A Comparative Study of the Hungarian and Italian Case (1990-2013). Politics in Central Europe 2016 (3): 51-82. available at https:// www.politicsincentraleurope.eu/documents/file/PCE_2016_3_12_a.pdf (19 January 2019)

Ormos, M. (2019): Mussolini. Politikai életrajz. Kossuth Kiadó.

Paksa, R. (2012): A magyar szélsőjobboldal története. Jaffa Kiadó.

Passarelli, G.-Tourto, D. (2018): La Lega di Salvini. Estrema destra di governo. Il Mulino Editore.

Passarelli, G.-Tourto, D. (2012): Lega \& Padania. Storie e luoghi delle camicie verdi. Il Mulino Editore.

Ruzza, C.-Balbo, L. (2013): Italian Populism and the Trajectories of Two Leaders: Silvio Berlusconi and Umberto Bossi. In: Right-Wing Populism in Europe. Politics and Discourse. Ed. Wodak, R. 
et. al. Bloomsburry. Available at https://www.researchgate.net/publication/272160961_Italian_Populism_and_the_trajectory_of_two_leaders_Silvio_Berlusconi_and_Umberto_Bossi (19 January 2019)

Schmidt, A. (2016): Friends Forever? The Role of the Visegrad Group and European Integration. Politics in Central Europe 2016 (3): 113-140. Available at https://www.politicsincentraleurope. eu/documents/file/PCE_2016_3_12_a.pdf (19 January 2019)

Stojarová, V. (2018): Populist, Radical and Extremist Political Parties in Visegrad countries vis á vis the migration crisis. In the name of the people and the nation in Central Europe. Open Political Science 2018 (1): 32-45. Available at https://www.degruyter.com/downloadpdf/j/ openps.2017.1.issue-1/openps-2018-0001/openps-2018-0001.pdf (19 January 2019)

Szarka, L. (2016): A multietnikus nemzetállam. Kísérletek, kudarcok és kompromisszumok Csehszlovákia nemzetiségi politikájában 1918-1992. Pesti Kalligram Kft.

Tanács-Mandák, F. - Nuber, I. (2017): Az olasz képviseleti demokrácia. Dialóg Campus Kiadó.

Vörös, Z. (2016): Directions for development of political systems - decrease in legitimacy. In Pająk-Patkowska, B. - Rachwat, M. (2016): Hungary and Poland in Times of Political Transition. Selected Issues. Faculty of Political Science and Journalism Adam Mickiewicz University. Waczławczyk, W. - Laros, A. ed. (2017): The Process of Politicization. How Much Politics Does a Society Need? Copernicus Graduate School Studies, vol. 5. Cambridge Scholars Publishing.

Petra Hamerli is assistant lecturer at the Department of Political Science and International Studies of the University of Pécs (Hungary). She did a PhD in History in a co-tutelle programme at the University of Pécs and at the Sapienza University of Rome. Her research area is Italian-Hungarian diplomatic relations in the 20. century, and Italy's political system in the 20-21. centuries. 